\title{
Suriyeliler ve Vatandaşlık: Yerel Halk ve Suriyeli S1- ğınmacılar Çerçevesinde Bir Değerlendirme
}

\author{
DOI: $10.26466 /$ opus.341263
}

*

\begin{abstract}
$\underline{\text { Melike Gülyașar }}^{*}$
${ }^{*}$ Necmettin Erbakan Üniversitesi, SosyalBilimlerEnstitüsü, Konya/Türkiye

E-Posta: melikeglysr@gmail.comＯRCID: 0000-0001-5819-8409
\end{abstract}

Öz

Çalışmanın konusunu günümüzde önemli bir tartışma alanı oluşturan Suriyelilere vatandaşlık verilme ihtimalinin Suriyeliler ve Türkler tarafindan nasıl karşılandiğı ve bunun gerekçeleri oluşturmaktadır. 2011 yılından itibaren Arap Baharının Suriye'ye sıçrayıp aniden şiddetlenmesiyle Suriyelilerin sığındı̆̆ı ülkelerin başında Türkiye gelmektedir. Bu anlamda daha önce bu kadar yoğun göçle karşılaşmamış Türkiye'nin insani gerekçelerle sığınmacılara kapı açı onları kabullenmesi önemlidir. Ancak zaman geçtikçe Suriye'de savaşın bitmesinin giderek zorlaşması ve bu anlamda geçici oldukları dü̧̈ünülen sı̆̆ıımacıların kalıcı hale gelişi vatandaşlık konusunu gündeme getirmiştir. Dolayısıyla günümüzde en önemli tartışma alanlarından birini oluşturan Suriyelilerin vatandaşlık alması incelenmesi gereken önemli bir husus olarak karşımıza çıkarken bu konuda literatürde ciddi bir boşluk olduğu değerlendirilmekte, konuyla ilgili mevcut çalışmalara bakıldı̆̆ında ise sadece kısa değinmeler olduğu görülmektedir.Çalışmada Suriyelilerin vatandaşlık konusunda düşündükleri, vatandaşlık verilmesi halinde kabul edip etmeyecekleri ve vatandaşlığın onlara, onların ise Türkiye'ye ne gibi katkıları olacağı konusu mülakat tekniği kullanılarak ortaya koyulmuştur. Türk halkının bu konudaki görüşleri ise Murat Erdoğan'ın yaptı̆̆̆ Toplumsal Kabul ve Uyum adlı çalışmada yapılan mülakatlar, sosyal medya üzerinden oluşturulan tepkiler ve çeşitli çalışmalar analiz edilerek ortaya koyulmaya çalışılmıştır. Araştırmada elde edilen bulgular ise Suriyeliler nezdinde çoğunlukla vatandaşlı̆̆a sıcak baktıkları, vatandaşlık verilmesi halinde kendilerini daha garanti altında hissedecekleri, daha iyi ve eşit şartlarda yaşayabilecekleri üzerine iken Türklerin düşünceleri ele alındığında tam aksine büyük çoğunluğun vatandaşlık verilmesine karşı olduğu bunu milliyet unsuru, günümüzde Suriyelilerin çıkardığı düşünülen pek çok sorun, vatandaşlık verilmesi halinde burada kalacakları endişesi, ekonomik anlamda yük olarak görülüyor oluşları gibi pek çok nedene dayandırdıkları ortaya koyulmuş bu bağlamda Türklerin ve Suriyelilerin düşüncelerinin büyük farklllılar gösterdiğ $i$ görülmüştür.

Anahtar Kelimeler: Suriyeliler, Türkler, sı̆̆ınmacı, vatandaşlık, vatandaşlığın kabulü 


\title{
Syrians and Citizenship: An Evaluation on the Local People and Syrian Asylum Seekers
}

\author{
DOI: 10.26466/opus.341263
}

\begin{abstract}
The subject of the study consists of the possibility of giving citizenship to Syrians which creates a discussion field and how it is perceived by Turks and the reasons for this. Since 2011 when Arab Spring leaped to Syrian and immediately intensified, Turkey is one of the main countries where Syrians took refuge. In this sense, it is important that Turkey which has never encountered with such intense immigration so far welcomed and accepted the refugees with humanitarian justifications. However, as the end of the war in Syria became more difficult as the time went by, and in this sense, the fact that refugees who were thought to be temporary became permanent brought up the issue of citizenship. Thus, while the issue that Syrians receive citizenship emerge as an important question creating one of the most important discussion fields today, it is evaluated that there is a serious gap in the literature on this subject and when the available studies related to the topic are examined, it is observed that there are only short references on it. The topic of what Syrians think about the issue of citizenship, whether they would accept it or not in the case of receiving citizenship, what kind of contribution citizenship would provide to them and in turn, what kind of contribution they would provide to Turkey are revealed in the study with the interview technique. It was attempted to reveal the opinions of Turkish people through interviews done in the study "Social Acceptance and Harmony"carried out by Murat Erdoğan, social reactions created via social media and by analyzingvarious studies. The findings obtained in the study demonstrated that, in the eye of the Syrians, while the majority leaned towards the citizenship, predicating their views on reasons such as that they would feel themselves more guaranteed in the case of receiving citizenship, they would live at better and equal conditions, when the opinions of Turks are approached, quite the contrary, it was demonstrated that the majority opposed giving citizenship and based this on the justifications of nationality factor, many problems thought to be created by Syrians, the anxiety that they would stay here in the case of giving citizenship, the fact that they are perceived as a burden in the economic sense and within this context, it was observed that the opinions of Turks and Syrians demonstrated great differences.
\end{abstract}

Key Words:Syrians, Turks, refugees, citizenship, acceptance of citizenship 


\section{Giriş}

Arap coğrafyasında 2011 yılında başlayan yönetimlere karşı tepkiler giderek büyümüş ve bugün adına "Arap Baharı" denilen olayları meydana getirmiştir. Halkın otoriter rejimlere karşı isyanıyla birlikte olaylar giderek artmış ve bazı ülkelerde sorunlar hallolurken Suriye' de ise olaylar bugünkü boyutuna ulaşmıştır. Suriye' de yaşanan bu savaş halinin en çok etkilediği ülkelerin başında da Türkiye gelmektedir. Türkiye bugün ortalama 3,5 milyon Suriyeliye ev sahipliği yaparak en çok Suriyeli sı̆̆ınmacı kabul eden ülkeler arasında önemli bir yerde durmaktadır.

Suriyelilerin Türkiye'ye sığınması geçici bir süreç olarak görülüp halk tarafından da kabul edilmiş olsa da günümüzde giderek kalıcı hale gelişleri ve bu süre zarfında yaşanan, medya tarafından yansıtılan olaylar bir Suriye sorunu oluşturmaya başlamıştır. Bu kalıcılığın beraberinde getirdiği en önemli tartışmalardan birisi de burada uzun zamandır kalan ve kalmaya devam edecekleri tahmin edilen Suriyelilerin buradaki kimliklerinin, haklarının yetersiz olmasına ilişkin şikayetleri, düşünceleri ve Türk vatandaşların buna ilişkin tepkileridir. Bakıldığı zaman Suriyelilerin bugünkü hakları ve konumları üzerinde belli iyileştirmeler yapılmış olsa da bunlar geçici oldukları düşünülerek sunulan haklar olduğu için giderek kalıcı hale gelen ve burada düzen kurma zorunluluğu yaşayan Suriyeliler için yetersiz kalmaktadır.

Mülteci tanımlamasına yerleştirilmesi imzalamış olduğumuz Cenevre sözleşmesindeki "Avrupa'dan gelenler" ibaresinden ötürü mümkün olmayan Suriyelilerin mevcut mevzuatın eksikliklerinin görülmesiyle birlikte 2013 yılında getirilen terimlerle tanımlandıkları görülmektedir. Değişimle birlikte mülteci, şartlı mülteci, ikincil koruma, geçici koruma terimleri getirilmiş mülteci kavramı da aynı şekilde kalmıştır (IMPR, 2014, s. 4).

Suriyelilerin konumları da bu değişiklikle ikincil koruma statüsü elde etmelerini sağlamıştır. Buna göre "mülteci veya şartlı mülteci olarak nitelendirilemeyen, ancak menşe ülkesine veya ikamet ülkesine geri gönderildiği takdirde; Ölüm cezasına mahkûm olacak veya ölüm cezası infaz edilecek, işkenceye, insanlık dışı ya da onur kırıcı ceza veya muameleye maruz kalacak uluslararası veya ülke genelindeki silahlı çatışma durumlarında, ayrım gözetmeyen şiddet hareketleri nedeniyle şahsına yönelik 
ciddi tehditle karşılaşacak olması nedeniyle menşe ülkesinin veya ikamet ülkesinin korumasından yararlanamayan veya söz konusu tehdit nedeniyle yararlanmak istemeyen yabancı ya da vatansız kişiye, statü belirleme işlemleri sonrasında ikincil koruma statüsü verilir" (madde 63) (IMPR, 2014, s.4). Ancak bakıldığı zaman bu statü onlar için bir belirsizlik demektir. Onların yasal haklar elde edip edemeyecekleri bugün hala belirsizliğini korumakta, Suriyeliler için vatandaşlık verilmesi daha büyük bir önem arz etmektedir. Ancak Türkiye'nin bir ulus devlet olduğu göz önünde bulundurulursa vatandaşlık söz konusuyken milliyetçiliğin ön planda duruşu Suriyeliler için vatandaşlık konusunu hem devlet hem halk nezdinde zorlaştırabilmektedir.

Yukarıda belirtilen hususlar ekseninde bakıldığında Suriyelilere vatandaşlık verilmesi konusu önemli bir yerde durmaktadır. Çalışmada da bu konunun önemi göz önünde bulundurularak Suriyelilerin vatandaşlık verilmesine nasıl baktıkları, isteyip istemedikleri ve bunu hangi gerekçelere dayandırdıkları Suriyeli sığınmacılarla yapılan mülakatlar ile ortaya koyulmaya çalışılmıştır. Yapılan mülakatlar sunulurken katılımcı gizliliğinin sağlanması adına takma ad (pseudonym) metodu kullanılmıştır. Diğer taraftan ise Türklerin, Suriyelilere vatandaşlık verilmesi konusunda ne düşündükleri gerek yapılan çalışmalar gerekse sosyal medyada ortaya koyulan tepkiler incelenerek ortaya koyulmaya çalışılmış ve çalışmada her iki çerçeveden de bakışın sağlanması amaçlanmıştır.

\section{Vatandaşlik}

Vatandaşlık olgusu özellikle ulus devlet sürecine geçişle birlikte varlığ1 daha görünür bir hal almış ve bu anlamda günümüzde de özellikle artan göçlerle birlikte etkisini giderek arttıran bir tartışma alanı oluşturan kavram olarak karşımıza çıkmaktadır.

Günümüzde bu derece önemli bir hal almış olan vatandaşlığın tam olarak ne ifade ettiği de önemli bir husustur. Genel anlamda vatandaşlık; belli bir vatana ait olma ve o vatanın ortak değer, yasal düzenlemeler, örf vb. toplumsal düzenlemelerine uyma davranışı olarak ifade edilebilir (Uğurlu, 2011, s.154). 
Aynı zamanda önemli sosyologların da vatandaşlığa ilişkin sosyolojik perspektiften tanımlamaları mevcuttur. Turner'a bakacak olursak vatandaşlığ 1 "bir kişiyi toplumun yetkin bir parçası olarak tanımlayan ve bunun sonucunda kaynakların kişilere ve sosyal gruplara akışını şekillendiren bir dizi (hukuki, siyasi, ekonomik ve kültürel) uygulama" olarak ifade ederken; Marshall ise vatandaşlığı bir topluluğa aidiyet olarak tanımlamıştır (TBMM Araştırma Merkezi, 2011, s.1).

Genel anlamda bakıldığında vatandaşlık çok çeşitli unsurları da içinde barındırmaktadır. Vatandaşlık bireylere haklar sağlarken aynı zamanda sorumluluklar da yükleyen bir yapıdır. Kısaca vatandaşlık bireylere bir siyasal katılma fırsatı ve yükümlülüğü getirir. Vatandaş olduğu takdirde birey seçimlere katılacak, vergi verecek, toplumsal ve siyasal kuruluşlarda çalışacak ve başkalarına yardım edecektir. (Çarkoğlu\& Kalaycığlu, 2014, s.21).

Ancak vatandaşlık salt siyasal ve hukuki bir yapı değil aynı zamanda o bireylerin aidiyetini de sağlayan bir unsurdur. Bireyler vatandaşı oldukları ülkeye aidiyet duygusu ile bağlanırlar. Aidiyet konusu Suriyelilere yöneltilen vatandaşlık konusuna ilişkin sorulara karşılık verilen cevaplarda da karşımıza oldukça fazla çıkmaktadır. Suriyelilerin azımsanmayacak bir kısmının vatandaşlık verilirse buraya ait bir kimliği, bir aidiyeti olacağını söylemesi çalışma açısından dikkat çeken bir nokta olmuştur.

Günümüzde Türkiye açısından en büyük göç hareketi olarak Suriyelilerin gelişi ele alınacak olursa da vatandaşlık oldukça önemli bir yer tutmaktadır. Şöyle ki yaşanan Arap Baharı'nın Suriye'de kanlı bir süreç haline dönüşmesiyle birlikte Suriye'den gelen yoğun göçün etkilediği ülkelerden birisi de Türkiye'dir. Şu an için ortalama 3.5 milyon olan Suriyelilerin geçici olarak buraya gelmedikleri ve savaşın kolay kolay bitmeyeceği düşünüldüğünde daha uzun soluklu politikalar gerçekleştirilmesinin gereği ortaya çıkmıştır. Bu bağlamda hem Türkler için hem Suriyeliler için en çok tartışma konusu olan vatandaşlık verilme hususu gündeme gelmiştir. 


\section{Dünyada Vatandaşlık}

Vatandaşlık olgusunun hem hukuki hem de toplumsal alanda bir karşılığını bulmak söz konusudur. Bu iki ayrı çerçeveden de bakıldığında dünyada ve ülkemizde farklı vatandaşlık tanımlamalarıyla karşılaşmak mümkündür. Özellikle ulus devletleşme sürecinden sonra yoğun bir milliyetçilik etkisine ve milliyetçi yapıya daha uzak çok uluslu yapıya sahip devletlerle karşılaşılabilmektedir. Bu anlamda belirtilen şartlar ve kriterler o ülkenin yapısını da ortaya koymaktadır. Dolayısıyla göç eden bireylerin buralarda vatandaşlık elde ederek çeşitli haklar kazanabilmesi durumu ülkelerce farklılık göstermektedir. Günümüzde en büyük göç hareketini oluşturan Suriyeliler için de vatandaşlık sürecinin nasıl işlediği ve işleyeceği bu şekilde ifade edilebilir.

$A B D$ Anayasasının 14. maddesine göre $A B D^{\prime}$ de doğan veya $A B D$ vatandaşlığına kabul edilen ve ABD'nin yetki alanına tabi olan kişiler $A B D$ 'nin ve ikamet ettikleri eyaletin vatandaşıdır. Alman anayasasında "Alman" terimi, "Alman vatandaşlığına sahip olanlar veya Alman soyundan olup 31 Aralık 1937 tarihindeki Alman İmparatorluğu sınırları içinde kabul edilmiş olan mülteci veya sürgün edilenler ile bunların eşi" veya altsoyu anlaminda kullanılmaktadır. Bulgaristan Anayasasının ise 25. maddesine göre, annesi ve/veya babası Bulgar vatandaşı olan veya Bulgaristan Cumhuriyeti topraklarında doğan herkes kökeninden dolayı başka bir ülkenin vatandaşlığına hak kazanmadıkça Bulgar vatandaşıdır. Son olarak Polonya Anayasasının 34. maddesinde Polonya vatandaşlı̆̆ının, Polonya vatandaşı ebeveynlerden doğum ile edinildiği belirtilmektedir. Diğer vatandaşlık edinme yolları ise kanunla belirlenmektedir (TBMM Araştırma Merkezi, 2011, ss. 4-9).

Ulusal vatandaşlık tanımında geleneksel hukuki ölçütler doğum yeri ve neseptir. Anayasalarda yer alan vatandaşlık tanımında, nesep ölçütüne, yani kişinin ebeveynlerinin vatandaşlığını kazanmasına genellikle daha sık rastlanmaktadır (Almanya, Estonya, Finlandiya, Litvanya, Macaristan ve Polonya). Bununla birlikte, doğum yeri, yani kişinin doğduğu yerin vatandaşlığını alması ölçütü ve soy bağı ölçütünün beraber kullanıldığı da görülmektedir (Bulgaristan ve İrlanda). Yabancı dahi olsa, jussoliesasına dayanarak vatandaşlık verilmesini öngören tek anayasa ABD Anayasasıdır (TBMM Araştırma Merkezi, 2011, s.12). 
Küreselleşme süreciyle birlikte göçlerin artmasıyla ulus devlet yapılarının homojenliği azalmış ve dünyada artık vatandaşlık anlayışı çok kimlikli bir boyut kazanmaya başlamıştır. Ancak bu çok kimlikli boyut mülteciler, sığınmacılar yani özelde de Suriyeliler söz konusu olduğunda geçerliliğini yitirmektedir. Bugün Avrupa sığınmacılara kapılarını kapamış Türkiye'ye de özellikle de Avrupa Birliği'nde "Doğu sınırınızı açın, sığınmacılar gelsin, ama Batı sinırınızı kapatın, bize gelmesinler" yaptıkları çağrı Suriyelilere karşı tutumlarını açıç̧a göstermiştir (Erdoğan, 2014, s.16). İncelendiği zaman dünyada özellikle Batı diye tabir edilen ülkelerin vatandaşlık vermeye ilişkin konuları kanunda özel olarak düzenlemeye tabi tuttuğu görülmektedir. Bu anlamda Suriyelilere yönelik politikaları da eğitimli ve zengin olmayan daha realist bir açılamayla onların işine yaramayacak kişilerin alınmaması ve vatandaşlık verilmemesi üzerinedir. Ancak eğitimli ve zengin kesimi hemen ülkelerine kabul etmekte ve onlara vatandaşlık verme sürecini gerçekleştirdikleri görülmektedir.

\section{Türkiye'de Vatandaşlık}

Türkiye'de vatandaşlık kriterleri özellikle ulus devletleşme sürecinde giderek milliyetçi bir hale bürünmüştür. Resmi çerçevede vatandaşlı̆̆ın ne olduğuna bakmak için anayasaya bakmak gerekmektedir. Anayasal kabulde, “Türk Devletine vatandaşlık bağı ile bağlı olan herkes Türk'tür. Türk babanın veya Türk ananın çocuğu Türk'tür. Vatandaşlık, kanunun gösterdiği şartlarla kazanılır ve ancak kanunda belirtilen hallerde kaybedilir"(1982 Anayasası m.66) (AnbarlıBozatay, 2010, s.171).

Bakıldığında Türk vatandaşı olmak sonradan da belli şartlar altında mümkün olsa da kan ve toprak esasının bir arada olması şartını getirmektedir. Yani anne veya babanın Türk olması yanında bir de Türkiye'de doğma şartı söz konusudur. Bu anlamda ABD'deki gibi Türkiye'de doğmuş bebeklerin Türk vatandaşı olması söz konusu olmadığı için Suriyelilerin burada doğan çocukları da sanılanın ve beklenenin aksine vatandaşlığa alınmamaktadır. Bu bağlamda Suriyelilerin en merak ettiği konulardan biri Türk vatandaşlığı kazanımı ile ilgilidir. Türk vatandaşlığını kazanma başvurusu için 5 ylllık ikamet süresi gerekmektedir ancak bu durum geçici koruma kapsamındaki kişiler için geçerli değildir. Türk vatan- 
daşlığı evlenme yoluyla da elde edilebilir. Evliliğin 3 yıl sürmesi ve evliliğin gerçek olması kaydıyla Suriyeliler Türk vatandaşlığı kazanılabilmektedir (Aile ve Sosyal Politikalar Bakanlığı, 2016, s.106). Bir başka ihtimal ergin olmayan geçici korunanın 17. madde uyarınca bir Türk tarafından evlat edinilmesi suretiyle vatandaşlık kazanmasıdır. Türkiye' de doğan çocuklar bakımından, Suriyeli ana ve babasından dolayı doğumla herhangi bir ülkenin vatandaşlığını kazanamaması halinde de, madde 8 uyarınca doğum yeri esasına göre çocukların doğumdan itibaren Türk vatandaşı sayılmaları da bir başka ihtimaldir. Lakin Suriyeli geçici korunanların 11. maddede düzenlenen genel başvuru yoluyla da Türk vatandaşlığını kazanmaları yolu, Geçici Koruma Yönetmeliği ile kapatılmıştır. Tüm bu usuller bakımından geçici korunanlar her türlü şartı taşısalar da, vatandaşlık sağlanması konusunda idare tam bir takdir hakkına sahiptir. Başvurular geçici korunanlara mutlak bir hak sağlamamaktadır (SETAV, 2015, s.64).

Vatandaşlık kavramının anayasada nasıl tanımlandığı kadar önemli olan bir diğer husus ise toplum nezdindeki vatandaşlık tanımlamasıdır. $\mathrm{Bu}$ anlamda toplumda vatandaşlığın ne şekilde tanımlandığı ve nelerin kabul gördüğünü yapılmış vatandaşlık araştırmasında görmek mümkündür.

Toplum vatandaş olmak için en çok "hukuki statünün yeterli olduğu" yargısına katılıyor. Toplumun yüzde 63'ü hukuki statünün yeterli olduğunu belirtirken, yüzde 52' si Türkçe konuşmak gerektiği, yüzde 41'i Müslüman olmak gerektiği, yüzde $38^{\prime} \mathrm{i}$ ise Türk ırkından olmak gerektiği fikrine katıldığı görülmektedir (KONDA ve İPM, 2016, ss.19-20). Aynı zamanda vatandaşlığın ne çağrıştırdığ1 sorulduğunda görüşülen kişilerin \%50'si vatandaşlı̆̆ın "yasalarda ifade edilen haklar" olduğunu \%20'si vatandaşlığ "yasalarda ifade edilen vazifeler," \%30'u ise "devlete üyelik" olarak tanımlıyor (KONDA ve IPM, 2016, s.13).Vatandaşlık araştırması esnasında görüşme yapılan kişilere "Türkiye'de insanları ortak bir vatandaşlık bağı ile birbirine hangisi bağlıyor?" diye sorduğumuzda, toplumun yaklaşık olarak üçte birinin din birliği, yine üçte birinin ortak gelenekler ve kültür vurgusu yaptığını görüyoruz. Her on kişiden biri dil birliğine vurgu yaparken, sadece beş kişiden biri birbirimizle "herkesi bağlayan yasalar" üzerinden vatandaşlık bağı kurduğumuzu düşünüyor (KONDA ve İPM, 2016, s.18). 
Son olarak bakıldığı zaman günümüzde Suriyelilere vatandaşlık konusu sıkça tartışılıyor olsa da belli sayıda kişiye vatandaşlık verilmiş ve bunların genelinin de yine Türk kökenli olduğu ortaya koyulmuştur. Dolayısıyla vatandaşlık verilmesi söz konusu olduğunda ilk bakılan husus soy olmakta ona göre vatandaşlık süreci işlemektedir. Belirtilen hususta Suriyelilere Türk olmaları halinde vatandaşlık verildiğine dair yapılan görüşmelerde de örneklere rastlanmıştır. Mülakatlardan bir pasaj paylaşmak gerekirse Ahmed'in bu konuda belirttiği gibi durumlar söz konusu olabilmektedir:

Şu an da vatandaşlık veriyor Türkiye Suriyeli bazı kişilere. Ama Türkçe bilip bilmediğine, eğitimine bakmıyor. Bir tanıdı̆̆ım var kadın. Aslı Türk diye ona vatandaşlık verildi. Ama Türkçe konuşamıyordu bile. Bence başka kriterler olmalı.

\section{Mülteci Mi Sı̆̆ınmacı Mı?}

Suriyelilere ilişkin bir tanımlama söz konusu olduğunda ilk karşımıza ç1kan BM'nin öncülüğünde Türkiye'nin imzalamış olduğu Cenevre Sözleşmesidir. Cenevre Sözleşmesi bugün hem Avrupa hem de Türkiye'de Suriyelilerin konumuna önemli bir etkide bulunmakta Türkiye'nin politikalarını etkilemektedir. Türkiye' nin bu sözleşmeyi imzalayarak başına "Avrupa'dan gelenler" cümlesini koyması nedeniyle Türkiye'deki Suriyeliler için mülteci demek doğru değildir.

Mülteci: "Irkı, dini, tabiiyeti, belli bir toplumsal gruba mensubiyeti veya siyasi düşünceleri yüzünden, zulme uğrayacağından haklı sebeplerle korktuğu için vatandaşı olduğu ülkenin dışında bulunan ve bu ülkenin korumasından yararlanamayan, ya da söz konusu korku nedeniyle, yararlanmak istemeyen yahut tabiiyeti yoksa ve bu tür olaylar sonucu önceden yaşadığı ikamet ülkesinin dışında bulunan, oraya dönemeyen veya söz konusu korku nedeniyle dönmek istemeyen her şahıs" olarak tanımlanmaktadır (IMPR, 2014, s.3).

Sığınmacı ise; "1rkı, dini, milliyeti, belirli bir toplumsal gruba üyeliğ i veya siyasi düşünceleri nedeniyle takibata uğrayacağından haklı olarak korktuğu için vatandaşı olduğu ülke dışında bulunan ve vatandaşı olduğu ülkenin himayesinden istifade edemeyen veya korkudan dolayı istifade etmek istemeyen ya da uyruğu yoksa ve önceden ikamet ettiği ülke 
dışında bulunuyorsa oraya dönmeyen veya korkusundan dolayı dönmek istemeyen yabancı" olarak tanımlanmaktadır (IMPR, 2014, s.3).

Günümüzde Suriye' de yaşanan iç savaşla birlikte gelen yoğun göç ak1nıyla birlikte mevcut mevzuatın eksikleri görülmüş ve bir değişim söz konusu olmuştur. Bu bağlamda 2013 yılında yeni bir kanun yayınlanarak uluslar arası koruma çeşitlerine yeni kavramlar getirilmiştir. Değişimle birlikte mülteci, şartlı mülteci, ikincil koruma, geçici koruma terimleri getirilmiş mülteci kavramı da aynı şekilde kalmıştır (IMPR, 2014, ss. 3-4).

$\mathrm{Bu}$ kavramlar dışında bir de ikincil koruma kavramının getirildiği görülmektedir. Buna göre "mülteci veya şartlı mülteci olarak nitelendirilemeyen, ancak menşe ülkesine veya ikamet ülkesine geri gönderildiği takdirde; Ölüm cezasına mahkûm olacak veya ölüm cezası infaz edilecek, işkenceye, insanlık dışı ya da onur kırıcı ceza veya muameleye maruz kalacak uluslararası veya ülke genelindeki silahlı çatışma durumlarında, ayrım gözetmeyen şiddet hareketleri nedeniyle şahsına yönelik ciddi tehditle karşılaşacak olması nedeniyle menşe ülkesinin veya ikamet ülkesinin korumasından yararlanamayan veya söz konusu tehdit nedeniyle yararlanmak istemeyen yabancı ya da vatansız kişiye, statü belirleme işlemleri sonrasında ikincil koruma statüsü verilir" (madde 63) (IMPR, 2014, s.4). Bu bağlamda Suriyeliler için de ülkelerinden ayrılmaya zorlandıkları ve korunmak amacıyla sınırlarımızı geçen yabanclar olarak geçici koruma statüsü verilmektedir.

Ancak ORSAM'ın $(2016$, s.5) çalışmasında da belirtildiği gibi sadece Suriyeli mültecilere uygulanan bu geçici statü Türkiye'de herhangi bir orta ya da uzun vadeli beklentinin öngörülmesini zorlaştırmaktadır. Kentsel alanlarda birçok mülteci gelecekte yasal olarak çalışıp çalışamayacaklarına ya da vatandaşlık hakları elde edip edemeyeceklerine dair belirsizlik içinde köseye sıkışmış hissediyor. Bu sorun, Suriyeli mülteciler ve yerel otoritelerden merkezi hükümete kadar, resmi kurumlar arasındaki iletişim kanallarının yetersizliğiyle daha da pekişiyor.

Genel anlamda bir değerlendirme yapılırsa Türkiye'nin geçirdiği ulus devletleşme sürecinin beraberinde getirdiği milliyet kavramı ile birlikte Suriyelilerin bugünkü süreçte toplumda karşılaştığ1 vatandaşlık verilme sorunu önemli bir boyut kazanmıştır. Günümüzde vatandaşlık bizim için de milliyetle eş değer görüldüğ̈u için buraya göç eden pek çok Türk kö- 
kenli bireye (özelde Suriyelilere) vatandaşlık verilebilirken başka kökenden olanlar için bu durum daha zor şartlar altında gerçekleşmekte hatta toplum tarafından karşı çıkılan bir husus olmaktadır. Bu bağlamda yapılan görüşmeler ve literatür incelemeleri neticesinde elde edilen bilgilerle Suriyelilerin ve Türklerin vatandaşlığa nasıl baktığ incelenecek, karşılaştırmalı bir şekilde ortaya koyulmaya çalışılacaktır.

\section{Suriyelilerin Türk Vatandaşlığına Bakışı}

Suriyeliler Türkiye'ye ilk geldiklerinde savaşın Arap Baharını yaşayan diğer ülkelerdeki gibi kısa sürede biteceği ve Suriyelilerin ülkelerine geri döneceği düşünülmüştür. Bu anlamda politikalar bu yönde geçici olma durumuna göre belirlenmiş, halk da bu geçiciliği düşünerek Suriyelileri kabullenmiştir. Ancak savaş halinin giderek uzamış olması ve daha da uzun zaman bitmeyeceğinin ortada oluşu hem Suriyeliler hem devlet hem de Türkler açısından sorunlar oluşturmaya başlamış bundan dolayı yeni politikalara ihtiyaç duyulmuştur. Aynı zamanda bu kalıcılığın getirdiği en büyük söylemlerden biri olan vatandaşlık verilme konusu da gündeme gelmeye başlamıştır. Genel anlamda yapılan görüşmelerde ve daha önce yapılmış çalışmalarda değinildiği kadarıyla Suriyelilerin çoğunlukla vatandaşlık isteminin olduğu görülebilirken; Türklerin de tam tersi şekilde genellikle vatandaşlık verilmesine karşı çıtığı görülmektedir. Bu bağlamda çalışmada da esas değinilecek olan nokta Türkler ve Suriyelilerin, Suriyelilerin vatandaşlık alması hususuna bakışlarını irdelemek ve karşılaştırmalı bir şekilde bunu ortaya koymaktır.

Suriyeliler genel anlamda vatandaşlık istese de bazılarının da istemiyor oluşu gözden kaçmaması gereken bir noktadır. İlk olarak vatandaşlık hakkı almak isteyenlerin neden istediği yapılan görüşmeler ve literatür taramaları ile irdelenecektir. Çalışmamız için gerçekleştirilen görüşmelerde bu konuya yönelik en temel soru "Suriyelilere vatandaşlık verilmesi ile ilgili ne düşünüyorsunuz? Siz Türk vatandaşı olmak ister misiniz? Olduğunuz zaman sizin için neler değişir size nasıl katkı sağlayacağını düşünüyorsunuz? Size ne fayda sağlar? “ şeklinde yöneltilen sorudur. Bu soruya genel olarak belli cevaplar alınırken farklı cevapların da olduğu görülmektedir. 
Suriyelilerin vatandaşlık almayı isteme nedenlerinde ilk sırada iş konusu gelmektedir. Suriyeliler şu anda genellikle kendi meslekleri olmayan işlerde düşük ücretlerle ve sigortasız olarak çalışmakta olmaktan bu anlamda emeklilik konusunun da akıllarında soru işareti oluşturmasından şikayetçidirler.

Ahmed: Gençlerimiz fabrikalarda ucuza çalışıyor aslında sizin ekonominize onlar destek oluyor. Şu an ki ekonomik sıkıntıların sebebi yaşanan olaylarda etkilidir. Bende vatandaşlık alıp haklara sahip olmak isterim şimdi hiçbir hakka sahip değilim ve çok düşük ücrete çalıştırillyorum.

Azze: Bize Türk vatandaşlığından önce haklarımız verilmeli. Vatandaşlık çok önemli değil öncelikle haklarımızı almak isteriz. Şimdi bize çok farklı davranılıyor. Sizinle aynı değiliz. Bizim eşlerimizin sigortası yok, az para alıyorlar.

Görüldüğü üzere görüşme sırasında karşılaşılan durumlardan birisi vatandaşlığın şart olmayışı ancak vatandaşlığın getireceğini düşündükleri hakların onlara verilmesi gerektiğine ilişkindir. Suriyeli kadın ve erkekler bu anlamda en çok şikayetçi oldukları emeklerinin karşılığını alamama durumunun önlenmesini istemektedirler.

Ahmet: Vatandaşlık verilmesini çok istiyoruz çünkü ben ve ailem artık Türkiye'de yaşayacağız. Suriyeliler, fabrikalara girip çalışır, emekli olur, sigorta yatar artık bizlere devlet size bakıyor boş boş oturmayın demezler bizde bu ülkenin vatandaşı oluruz, bu ülkedeki insanlar ne yapıyorsa bizde hepsini rahat rahat yapariz ve bu ülkeye hizmet ederiz.

Mirvan: Bu ülkede uzun süre kalacaksak vatandaşlı verilmesini istiyoruz. Ben Türk vatandaşı olmak istiyorum, Türk vatandaşı olduğum zaman dükkânım yasalara uygun olur, şuan bana kızıyorlar devlete para vermiyorum, Pazar günü dükkam açıyorum, kontrol edilmiyor diye kızıyorlar. Vatandaşlık verilirse Türk berberler nasılsa bende öyle olmak isterim. Bende bu ülke için çalışıp bu ülkeye faydali olurum.

Yukarıda belirtildiği gibi Suriyeliler işlerini rahatlıkla yapamamaktan, yardımlarla geçinmekten ve onların elinde olmayan sebeplerden dolayı Türkler tarafından tepki gösterilmesinden şikâyetçidirler. Bunun da vatandaşlık verilince önleneceğini düşünerek bu doğrultuda bir talep oluşturdukları görülmektedir. Vatandaşlık verildiği takdirde vergilerini verip Türklerle eşit yükümlülükleri de olacağı ve yük olmaktan da çıkabileceklerini bu anlamda tepkilerden kurtulabileceklerini düşünmektedirler. 
İş konusunda değinilmesi gereken önemli bir nokta ise kendi mesleklerini yapamıor olmaları ve devlet memurluğu isteklerinin vatandaş olmadıkları için bir karşılığı olmamasıdır.

Muhammed: Bence artık Suriyelilere vatandaşlık verilmeli. Çünkü artık biz burada yaşıyoruz. Ĕğer ben Türk vatandaşı olursam bu ülkenin insanlarma da hizmet ederim. Devlet de çalışabilirim. Vergimi veririm. Çocuğum bu ülkeye hizmet eder. Bizde ne olduğumuzu gelecekte nerede olacağımızı biliriz.

Affan: Verilmesi lazım. Benim vatandaşlık almam burada iş kurmamı sağlayacak. O yüzden istiyorum. Mühendisim ben diplomam var o diplomayla çalı̧mak isterim.

İş konusunda son olarak ticaret yapan Suriyeliler ele alınacak olursa onların da şu anda sadece Suriyelilerle ticaret ortaklığı yapan kısıtlı ülkelerle ticaret yapabildikleri ancak Türk vatandaşı olmaları halinde bu ülkelerin fazlasıyla artabileceği ve ticareti büyüterek katkı sağlayacaklarını ifade ederek vatandaşlık talebinde bulunanlarla karşılaşmak mümkündür.

Abdulhakim: Ben vatandaşlik alırsam daha rahat ticaret yapabilirim. Şu an bana izin verilmiyor, Arap ülkeleri kabul etmiyor orada ticaret yapmami. Ama Türk gibi olursam o zaman daha iyi ticaret yapabilirim. Devlete katkı sağlar bu da.

Aynı zamanda yatırımcıların, Müstakil Sanayici ve İşadamları Derneği (MÜSİAD) ve Mevlana Kalkınma Ajansı'nın (MEVKA) sunduğu rapordaki görüşmelerde vatandaşlık talebinde bulundukları görülmektedir. Şu an için imkanlarının kısıtlı oluşu ve bunun vatandaşlıkla önlenebileceği görüşüyle yatırımcılar, belirli bir oranda yatırım yaptıklarında, kendilerine Türk vatandaşlığı verilmesi gerektiğini vurgulamaktadırlar. Bu konuda bir katılımcı "Büyük işadamları ve yatırım yapma gücü olanlara istisnai, geçici vatandaşlık verilerek doğrudan kendilerinin yatırım yapmaları sağlanabilir" şeklinde bir öneri getirmektedir (MÜSİAD \& MEVKA, 2015, s.80).

Ruksan da farklı bir bağlamda sınırda güvenli bölge oluşturma konusunda Suriyelilere ihtiyaç duyulacağına bu anlamda onların vatandaşlık alması gerektiğine dair bir noktaya değinmiştir.

Bence verilmeli vatandaşlık. Vatandaşınız olmak isterim. Bu Türk devletine de çok katkı sağlar. Türkiye serbest bölge talep ediyor. O bölgede sizi temsil edecek, arkanızdan vurulmanızı önleyecek ve aldığını yerleri muhafaza edip geliştirecek 
Suriyeli temsilciler lazım size. Bu yüzden tampon bölge için bizim vatandaş olmamı ve temsil edebilmemiz lazım sizi.

Kavramsal çerçevedeki tanımlardan hatırlanacağı üzere vatandaşlık salt siyasi anlamda bir unsur değil aynı zamanda bir kimlik kazanımını da ifade eden bir unsurdur. Bu kimlik olgusu aidiyeti de sağlayacağ için Suriyeli sığınmacılar burada vatandaşlık elde ettikleri takdirde kendilerini buraya ait hissedeceklerine, Türkiye'nin onların vatanı olabileceğine ve bu bağlamda Türkiye için daha faydalı işler yapabileceklerine dair ifadelerde bulunmuşlardır.

Cundi: Suriye'deyken burası artık benim ülkem değil diye düşünmeye başlamıştım. Türkiye'de ise ölene kadar yaşayabilirmiş gibi hissediyorum. Fakat vatandaşlı̆̆ım olmadan bu isteğim resmiyet kazanmıyor (URL1).

Rıfad: Her gün haberlere bakıyoruz vatandaşlık verilecek mi verilmeyecek mi diye bekliyoruz. Türk vatandaşı olmayı çok isterim ben Türkiye'yi çok sevdim, Türkiye'nin vatandaşı olmayı da istiyorum. Kendimi buraya daha çok ait hissedeceğim ve istediğim yerde rahat rahat çalışabileceğgim. Sigortam olacak, emekli olmayı düşünüyorum, çocuklarım burada okusun burada çalışsın, Türkiye de evlensin istiyorum.

Hasan: Umarım alırız. Çocuklarımızın geleceği için önemli görüyorum. Yaşadığın yere olan aidiyet önemli, biz kendimizi Türk olarak görüyorduk, çünkü dedelerimizin dedesi Türk idi. Şimdi has Türk olduk. Oğlum Muhammed 'in Türk askeri olarak vazife yapmasın isterim. Kızım Fufu da zaten doktor olacak inşallah, vatanına sahip çıkmasını diliyoruz. Artık bugünden sonra Suriye yok. Türk vatandaşı yeter. Suriye'ye başkaları gelir herhalde... Elli yılı bulur herhalde, çok uzun sürer. Belki torunlarımı gider.

Suriyelilerin en büyük sorunlarından biri de gelecek kaygısıdır ve bunun esas çözüm noktasının vatandaşlık verilmesi olduğunu düşünmektedirler. Daha önce belirtildiği gibi Suriyelilerin Türkiye'ye gelişi iki millet için de geçici bir süreç olarak düşünülmüş ve bu yönde bir tavır sergilenmiştir. Ancak Suriyelilerin giderek kalıcı hale gelmesi ve savaşın sonunun görünmüyor oluşu Suriyelileri gelecekleri konusunda kaygılandırmaktadir.

“Türkiye' de benim tahminime göre son dört senede doğan Suriyeli bebek sayısı 200 binin üzerinde. Hiçbirinin vatandaşlık hakkı yok. Suriye de onları 'vatan haini' olarak görüyor. Bu çocukların vatansız kalma tehlike- 
leri var. Yaptığımız bütün çalışmalar şunu gösteriyor: Kimse istemiyor vatandaş olmalarını" (URL2) ifadesini gördüğümüz haberdeki gibi Suriyelilerin ne olacağı ve Türkiye'den her an gönderilebilecek olma tehlikeleri onlar için endişe vericidir. Bunun önüne geçebilecek olanın da vatandaşlık olduğunu düşünmektedirler. Aynı zamanda şu anda bir yatırım yapamadıkları, her an gönderilme korkusuyla da yapmaya cesaretlerinin olmadığı gözden kaçırılmamalıdır.

Ali: Suriye'ye geri dönüş şartlarmmn zorluğu, mültecilerin Türkiye vatandaşlığı istemesinin en önemli nedenlerinden biri" diyor ve ekliyor:3 sene önce yaptığımı ankette, Suriyelilerin yüzde 90'ı Türkiye'de geçici olarak kaldığını ve ülkesine geri döneceğini düşünüyordu. Ancak şu an Suriye'de durumun çok kötüleştiğini herkes biliyor. Dönme şansımız kalmadı. Suriye'deki şartlara rağmen hala dönmek isteyenler olsa da, çoğumuz vatandaşlık istiyor (URL1).

Cundi: En büyük sorun, yarın ne olacağın bilmeden yaşamak. Hayatımdaki her şey geçici. Vatandaşlik almak belki bu belirsizlikleri yok eder (URL1).

Amine: Vatandaşlık verilmesi gerektiğini düşünüyorum. Çünkü Suriyeliler artık Türkiye'de yani. Çoğu Türkiye'de kalacak, çünkü başka gideceğimiz yer yok. Suriye'de savaş bitse de artık orada hiçbir şey yok. Evler, dükkânlar hep yıkıldı. Yeniden inşa edilmesi çok uzun zaman alır, zaten buraya alıştık, burada düzen kurduk, dönmek istemeyiz. Türk vatandaşı olursak artık bizi gönderirler mi korkusu olmayacak, burası da bizim ülkemiz olacak.

Yukarıdaki ve benzeri ifadelere bakıldığında Suriye'de artık hiçbir şeylerinin kalmayışı, geri dönme ihtimalinin zayıflamasından ötürü ne olacaklarına dair endişeleri onların vatandaşlık almasıyla son bulacağı düşüncesini oluşturmaktadır. Bu anlamda hem bizim yaptığımız çalışmada hem yukarıda değindiğimiz metindeki görüşmelerde Suriyelilerin geleceklerini güvence altına almasının yolunun vatandaş olmaktan geçtiği düşüncesi hakimdir.

Suriyelilerin vatandaşlık verilmesine dair görüşlerine ilişkin bir diğer boyut da vatandaşlığın istenmemesidir. Bunun sebebi daha çok buraya entegre olamama, burada aradığını bulamama ve vatandaşlık aldığı takdirde kendi vatanından vazgeçmiş olacağ türde çok daha az yer bulabilmiş bir süreç ve algıyı barındırmaktadır. 
Yusuf: Ben vatandaşlık verilmesini istemiyorum, kendi vatanın değil burası neden bu vatanın vatandaşı olmayı düşünüyor ki Suriyeliler onlar Suriye vatandaşı, geçmişini nasıl unutacak insanlar akrabalarını bir ülkenin vatandaşı olmak kolay değil. Biz buraya geçici olarak geldik ve savaş bittiği zaman geri döneceğiz.

Emani: Vatandaşlik istemiyorum biz böyle idare ediyoruz, Türkiye vatandaşı olmak istemem. Ben Suriyeliyim ve geri dönmek istiyorum. Ama eşim çocuklarım burada kalmak istiyorlar ve çifte vatandaşlık olmasını istiyorlar.

Emani ise vatandaşlık istememesini kadınların çok ihtiyaç duymamasına aynı zamanda kendisinin başka ülkeye (Norveç'e) gidecek olmasına bağlayarak açıklamıştır. Erkeklerin ise haklarının olması açısından vatandaşlık almasının önemini vurgulamıştır.

Aslında çok gerekmiyor bana. Şimdi mülteci sayılıyoruz ama vatandaşlık verilirse Türk gibi olacă̆ız. O yüzden istemem. Ayrıca erkeklere verilmesi kadınlara verilmesinden daha önemli. İş ve eğitim konusunda daha fazla imkânları olacak. Biz kadınlar evdeyiz bir şey yapmıyoruz çok lazım değil bize. Ama kardeşlerim çok fazla çalışıyor onların sigortasının olmasını isterim. Haklarımın tamamen olmasinn isterim.

Görüşmeler sırasında rastlanan en çarpıcı detaylardan birisi de kaçak yaşamanın daha rahat olacağı görüşüdür. Bakıldığı zaman:

Ahmed: Ben istemiyorum. Suriye' de iken de her şey kaçaktı. Fatura yoktu. Bence kaçak yaşamak daha güzel. Esed'in, askerlerin, muhaliflerin kimliği vardl. Bizim yoktu. Ben Türkiye'ye gelmeden önce muhalif kimliği almıştım. Ama kaybettim diyerek kaçak yaşamanın daha kolay olduğunu, yükümlülük gerektirmediğini belirterek halinden memnun olduğu ve bu şekilde devam etmek istediği görülmektedir.

\section{Suriyelilerin Türk Vatandaşı Olmasına Türklerin Bakışı}

Türklerin Suriyelilere vatandaşlık verilmesi hususuna dair ne düşündügüne bakıldığında büyük bir çoğunlukla bunun çok net bir şekilde reddedildiği görülmektedir. Bu durum Erdoğan'ın çalışmasında yapılan kamuoyu araştırmasında da görülmekte, Türk toplumunun Suriyeliler ile arasinda çok ciddi bir kültürel mesafe koyduğu, onlara vatandaşlık verilmesine hiç sıcak bakmadığı açık biçimde ortaya koyulmaktadır (Erdoğan, 2014, s.5). 
Suriyelilerin burada kalma süresinin uzaması ve bununla birlikte gelen vatandaşlık verilmesi söylemi Türkler açısından daha sonra belirteceğimiz pek çok nedenle reddedilmektedir. Ancak bakıldı̆̆ 1 zaman Suriyelilerin geri dönüş ihtimalinin çok zayıf oluşu ve burada yerleşik olma ihtimallerinin giderek artması onların bugünkü statüleriyle devamını mümkün kılmamaktadır. Vatandaşlık verilmesinin Türkiye vatandaşları için zararlı olacağı savunulsa da aksine bugünkü statülerinde devam etmeleri daha büyük külfetleri beraberinde getirecektir. Koyuncu'nun çalışmasında belirttiği gibi bu kesimler (eğitim, sağlık, kamu yardımları gibi) hali hazırda birçok kamu imkânından da faydalanmaktadır. Başka bir ifadeyle Suriyeliler özellikle maddi harcamaların yoğun olduğu birçok alanda zaten Türkiye Cumhuriyeti vatandaşları ile aynı ya da benzer imkânlardan faydalanmaktadır. Dahası bu imkanlardan faydalanırken statüleri gereği başta vergi muafiyeti olmak üzere Türkiye Cumhuriyeti vatandaşları için geçerli birçok yasal yükümlülükten de azadedirler (2016, s.19). Bu anlamda onların vatandaşlık elde etmesi iki taraf için de daha faydalı olacaktır. Aynı zamanda yine Koyuncu'nun değindiği önemli noktalardan biri de Suriyelilere ilişkin oluşan şikayetlerdir. Bunlar genellikle ucuz emek, çocuk işçiliği, vasıfsız eleman ihtiyacı, çalışma izinleri, yoksulluk, kamu yardımları gibi konuların çözümü de yine vatandaşlık ile mümkün hale gelecektir (2016, s.19).

Türk toplumu nezdinde ne gibi düşüncelerin hakim olduğuna bakmak olayı daha detaylı ele almayı sağlayacaktır.

Özellikle kültürel farklılığa vurgu yapan, ötekileştiren ve Suriyelilerin varlığını "sorun" olarak niteleyen insanların sayısı son derece yüksektir. "Suriyeli kardeşlerimiz" yaklaşımı toplumda çok yaygın gözlenememiştir. Suriyeliler, "Zulümden kaçan", "zor durumda olan insanlar" olarak tanımlanmakta ama "bizlerden birileri" olarak görmeme eğilimi dikkat çekmektedir. Bu durum kamuoyu araştırmasına da yansımıştır (Erdoğan, 2014, s.20). Bu "bizlerden birileri" gibi görmeme durumu en çok da vatandaşlık hususu söz konusu olunca kendini belli etmektedir. Savaşın zulmünden kaçıp buraya sığınan Suriyelileri halk gideceklerini de göz önünde bulundurarak bir şekilde kabul etmiş olsa da söz konusu vatandaşlık olduğunda durum oldukça farklı bir boyuta bürünmektedir. Daha önce de belirtildiği gibi milliyetçi bir vatandaşlık anlayışına sahip olmamız Suriyelilerin vatandaşlığa kabul edilme ihtimaline karşı oldukça sert 
tepkileri ortaya çıkarabilmektedir. Bu anlamda \#ülkemdesuriyeliistemiyorum başlı̆̆1 altında sosyal medya hesaplarında pek çok tepki gösterilmiş ve irk konusuna da değinilmiştir.

\section{Anıl 17 Şub \\ \#Ülkemde Suriyeliístemiyorum ÜLKEMDE TÜRK IRKINDAN BAŞKA IRK ISTEMIYORUM !}

Bu tepki de onlardan bir tanesidir.

Suriyelilerin kalıcı olmadığı ve bu anlamda vatandaşlığın da verilmeyeceği vurgusunu yapmak adına misafir oldukları vurgulanmaktadır. Erdoğan da buna değinerek Suriyelilerin "misafir" olduğu ve bu anlamda uyum gösterme zorunluluğu içinde bulundukları vurgusu sıklıkla tekrarlanmıştır. Burada "misafirlik" kavramının büyük ölçüde bir "sınırlama" kavramı olarak dile getirildiği gözlenmiştir (Erdoğan, 2014, s.20). Yerel halk, kendi etnik ya da dini özelliklerine yakın olan Suriyelilere daha sıcak bakarken, diğer Suriyelileri dışlamayı tercih etmektedir. Araplar Arapları, Kürtler Kürtleri, Türkler Türkmenleri daha olumlarken diğerlerini ötekileştirilmektedir. Her kitle diğer kitleyi ötekileştirmektedir (Erdoğan, 2014, s.21). Yapılan görüşmelerde de Konya için düşünüldüğünde Türkmen kesimin daha iyi tepkilerle karşılaştığı ve daha az sıkıntı çektiği ortaya koyulmuştur. Aynı zamanda vatandaşlık verilme süreci başlarsa da Türkmenlere vatandaşlık verilmesinin diğer kesimlere verilmesinden daha az tepki alacağı ortadadır. Ki yukarıda da belirtildiği gibi bazı Türk kökenli Suriyeliler belli şartlar dahilinde bu hakkı elde etmişlerdir.

Suriyelilerin vatandaşlık alması demek onların burada kalıcı olması ve bir daha hiç gitmeyecekleri düşüncesini oluşturmaktadır. Bu anlamda Suriyelilere yönelik bugün karşımıza çıan şikayetlerin de kalıcı olacağı endişesi vatandaşlık verilmesine karşı tepkileri oluşturmaktadır. Özellikle de henüz vatandaşlık almamışken pek çok sorun çıkardıkları düşünülen ve vatandaşlık aldıktan sonra daha da rahat hareket edip bunların fazlasını yapacaklarından endişelenen halkta buna karşı bir tepki de söz konusudur. 


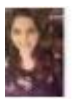

Süheyla

28 Şub

\#Ülkemdesuriyeliistemiyorum !

Türkçü Yazar@illedeturan

Mülteciyken bu kadar sorun çıkaranlar vatandaşığı alınca kim bilir neler yapar..

Suriyelilere ilişkin algının ilk geldikleri günlerden günümüze değiştiğini görmek mümkündür. Bu anlamda ilk olarak Türklerin Suriyelileri kabul gerekçelerine bakmak bunu daha rahat ortaya koymayı sağlayacaktır. Erdoğan bu konuya araştırmasında yer vererek katılımcılara bu soruyu yöneltmiştir. \%64,6 ile insanlık görevi olarak algılanması dikkat çekicidir(Erdoğan, 2014, s.24).

"Suriyeli sı̆̆ınmacılar bizi ilgilendirmez, uzak durulmalıdır" önermesine katılmayanların oranı \% 45, $8^{\prime}$ dir. Buna katılanların oranı ise $41,6{ }^{\prime}$ dır. Diğer provokatif kontrol sorusu olan "Bu durum Suriye'nin iç işidir, sı̆̆ıımacılarm kabul edilmemesi gerekirdi" önermesine de katılmayanlar, katılanlardan daha yüksektir (Erdoğan, 2014, s.25).

“Türkiye'deki Suriyelilere ilişkin kanaatinizi en iyi aşağıdakilerden hangisi ifade eder?" şeklindeki soruya verilen cevapta ise Suriyelileri "zulümden kaçan insanlar", Türkiye'deki"misafirlerimiz" ve "din kardeşlerimiz" olarak tanımlayanların oranı \% 74'ü bulmaktadır (Erdoğan, 2014, s.25). Bakıldığı zaman Erdoğan'ın sunduğu verilerin 2014 yılına ait olması pek çok şeyin değişmesiyle birlikte verilerde de bir değişimi getirecektir. 2014 yılında henüz çok fazla olay olmaması ve Türk halkının Suriyelilere tahammül sınırının daha üst düzeyde olduğu gözden kaçmamaktadır. Ancak kalış süresi uzadıkça ve medyaya da yansıyan pek çok haberle beslendikçe olumsuz algı giderek artmakta bu bağlamda da olumsuz tutumların oranının daha da artmış olacağı göz önünde bulundurulması gereken bir nokta olmaktadır.

Suriyelileri "bize yük olan insanlar" ya da "asalaklar-dilenciler" olarak görenlerin oranı ise toplamda \% $26^{\prime}$ da kalmaktadır. Suriyeli sığınmacıların yarattığı tedirginlik ve reddiyenin esasları da bazı önermelerle test edilmiştir. Burada Türk toplumunun özellikle ekonomiye gelen yükü önemsediği anlaşılmaktadır. Halkın \% 70,8'si, Türk ekonomisinin sığın- 
macılardan dolayı zarar gördüğü görüşündedir (Erdoğan, 2014, s.26) .Bukonuda Türk halkından pek çok tepki görmek mümkündür. Aşağıda verildiği gibi sosyal medyada da buna yönelik örnekler mevcuttur. Ancak daha önce de belirtildiği gibi Suriyelilerin özellikle sanayideki vasıfsız işler ve mevsimlik işlerde oluşan işçi açığını kapatarak buraların tam kapasite çalışmasını aynı zamanda da Türklere göre çok daha az ücretle ve sigortasız çalışarak masrafları da en aza indirgemesi düşünülenin aksine ekonomimize katkı sağlamaktadır. Türk vatandaşlarının şikayetlerinden olan hiçbir vergi ve yükümlülüğe sahip olmama konusu da vatandaşlık verilmesi ile çözülebilecek bir husustur.

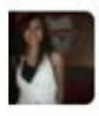

Aslıhan 28 Şub

Hastahaneler dolup tasiyor mahaslarini aliyorlar yiyecekleri masraflari bizden karsilaniyor ne olacak halimiz. \#Ülkemde Suriyeliístemiyorum

Kamuoyu araştırmasında özellikle 2014 yılında Ankara, Adana, Gaziantep gibi illerde Suriyelilere yönelik olarak yapılan gösterilerin ve zaman zaman fiili saldırılara dönüşen"eylemlerin" nasıl algılandığı sorgulanmıştır. Öncelikle "Suriyeli sığınmacılar bulundukları yerlerde şiddet, hırsızlık, kaçakçılık ve fuhuş gibi suçlara bulaşarak toplumsal ahlak ve huzuru bozmaktadır" önermesi ile genel kanaat ortaya çıarılmaya çalışılmıştır. Burada Türk toplumunun \% 62,3'ünün önermeyi desteklediği görülmüştür. Önermeye katılmayanların oranı \% 23,1'de kalmıştır (Erdoğan, 2014, s.29).

"Suriyeli sığınmacılar içinden bir kısım şahısların suç işledikleri gerekçesiyle, bazı şehirlerimizde sığınmacılara yönelik sert tepkiler gösterildi. Bu konuda görüşünüz nedir?"sorusuna yönelik olarak toplumun yarısının $(\% 47,5)$ tepkileri "haklı" görmesi ve"desteklemesi" dikkat çekicidir. Tepkileri haklı ama aşırı bulanlar \% 26,1; tepkileri ve saldırıları "haksız" bulanların oranı $\% 13,9$, Suriyelilerin haklarının devletin teminatı altında olması gerektiğini düşünenlerin oranı \% 12,4 olarak gerçekleşmiştir (Erdoğan, 2014, s.29).

Araştırmaya ve sosyal medyada \#ülkemdesuriyeliistemiyorum başl1ğında verilen örnek ve burada verilmemiş pek çok örnekteki tepkilere bakıldığı zaman Suriyelilerin sorun çıkaran kişiler olduğuna ve toplumun 
huzurunu bozduğuna dair görüşler yaygındır. Ancak bunun genellenebilecek bir durum olmadığı görülmelidir. Her toplumda sorunlu bireyler olabileceği gibi Suriye' den gelen sığınmacılarda da böyle kişiler söz konusudur. Suriyelilerin suça karışma oranlarının yerel halkın suç oranlarından çok daha düşük olduğu tespit edilmiştir. Buna rağmen algı abartılı biçimde olumsuzdur (Erdoğan, 2014, s. 19). Ancak bunun sürekli böyle yansitılması toplumda kötü bir izlenim bırakmıştır. Bu anlamda sı̆̆ınmac1lara sert tepki gösterilmesinin de haklı bir durum olduğu görüşülen kişilerin yaklaşık yarısının verdiği cevap olarak dikkat çekmektedir. Bu durum Suriyeli sığınmacıların da farkında olduğu ve bu sebeple onlara da kötü muamelede bulunulduğu bir durumdur. Bizim araştırmamızda da buna yönelik bir soru yönlendirilerek Suriyelilerin bu olaylarla karşılaşabildiği ortaya koyulmuştur.

Amine: Evet, böyle şeyler çok oluyor mesela ilk geldiğimiz yerde hergünhergün kavga oluyordu, çocukların tek başlarına sokağa çıkmalarım istemiyorduk. Orada kötü kötü arkadaşlar edinmişlerdi, küfür öğreniyorlardı. Tabi Konyalılar onlara bakıp bizde Suriyeli olduğumuz için bizi de öyle sanıyorlar ama mesela Türklerde de var hırsizlık yapan, içki içen, kavga eden o zaman bütün Türkler öyle mi oluyor. Ben karşılaşmadım ama böyle yani biliyorum.

Abdüllatif: Valla bunu ben duydum. Bizim arkadaşlar söyledi, benim hanım da söyledi. Bizim komşunun çocuğu arkadaşının ayakkabısını çalmış. Sonra bunu fark etmişler. Yani ben çok utandım, aç gezeceğiz ama kötü şey yapmayacă̆ız, sonuçta biz kardeşiz. [Bu yüzden size kötü davranan oluyor mu?] Bana olmuyor ama ben de rahatsız oluyorum çünkü Suriyeli dediğin zaman herkes kötü gözle bakıyor artık. Herkes öyle düşünüyor. Trene bindiğgimizde kimse yanımıza oturmuyor mesela.

Türk halkının burada görüldüğü gibi Suriyelilere ilişkin bazı olumsuz önyargıları olabilmekle beraber büyük kısmının onları savaşın ortasında terk etmeye vicdanlarının el vermeyeceği de çalışmalarda karşımıza çımaktadır. Bu konuda Erdoğan'ın çalışmasında Sığınmacılar savaş devam ediyor olsa bile ülkelerine geri gönderilmelidir şeklinde formüle edilen bir önerme sunulmuştur. Bu önermeye "katıliyorum" ve "kesinlikle katıllyorum" şeklinde destek verenler \%30,6'da kalmıştır. Türk halkının \% 62,8'i gibi çok ciddi bir bölümü bu önermeye katılmadıklarını ifade etmiş̧lerdir. Savaş hali" cümleden çıkarıldığında yani "Sığınmacılar, Türkiye'nin sorunu değildir, ülkelerine geri gönderilmelidir" önermesi sorulduğunda 
buna destek verenlerin \% 38,9,karşı çıkanların \% 47,8 olduğu görülmektedir. Bu durum "savaş hali" nin Türk toplumu için ciddi bir rol oynadığını ortaya koymaktadır (Erdoğan, 2014, s.30). Günümüzde her ne kadar yukarıda belirtilen sorunlar yaşandıkça, kalış süreleri uzadıkça ve vatandaşlık konusu gündeme geldikçe bu durum Türk halkı için sorun oluşturmaya başlıyor olsa da "gitsinler" söyleminde bulunan insanların pek çoğu onları savaşın ortasında savunmasız bırakmayı kabul etmeyeceği, dolayısıyla gitmelerine ilişkin bir durum olursa buna bizzat kendilerinin engel olacağı olasıdır.

Türk halkı "Suriyelilerin Türkiye'de kalmasının büyük sorunlara yol açacă̆̊ı" yönünde güçlü bir kanaate sahiptir. Bu önermeye "kesinlikle katıl1yorum" ve "katılıyorum" cevabı verenlerin oranı \% 76,5 gibi son derece yüksektir. Bu endişe bölge illerinde daha da yüksektir $(\% 81,7)$ (Erdoğan, 2014, s.30).

Vatandaşlık konusu en çok tartışılan ve sorun edilen konu olarak karşımıza çıkmaktadır. Erdoğan'ın araştırmasında da “Sığınmacılar Türkiye vatandaşlığına alınmalıdır" önermesine gelen destek sadece \%7,7'dir. Hiçbir konuda olmadığı kadar bu konuda \% 84,5 oranında net bir reddiye söz konusudur. Bu durumun ilerideki uyum politikalarında mutlaka göz önünde bulundurulması gereken, siyaseten de riskli bir alan olduğu anlaşılmaktadır (Erdoğan, 2014, s. 33). Türk halkının çok büyük bir kısmının vatandaşlık verilmesini istemediği görülmektedir. Aynı zamanda bu çalışmanın 2014'te yapıldığı göz önünde bulundurulursa 3 yılda yaşanan, medyada provokatif söylemlerle izleyicilere sunulan pek çok olay da düşünüldügünde ve halkın tahammül sınırının azaldığı görüldüğünden vatandaşlık verilmesini reddedenlerin oranının daha da yüksek olabileceği düşünülmektedir. Çalışmaya bakıldığında diğer konularda belli oranda bir kabul söz konusu olsa da vatandaşlık verilmesinin net bir şekilde reddedildiği görülmektedir. Bu da çalışmada daha önceki sorularda belirtilen sebeplere (ekonomik, kalma süresi uzadıkça artacak sorunlar, suç işleyen ve dilencilik yapan kesimler vs.) dayandırılabilmektedir.

Türkiye'nin Suriyelilere vatandaşlık verilmesine karşı çıkışı Suriyelilerin de farkında oldukları ve bu anlamda sürekli buna yönelik tepkilerle karşılaştıkları bir husustur. Görüşme sırasında Suriyelilere yönlendirilen “Bazı Türkler Suriyelilere vatandaşlık verilmesine karşı çıkıyor. Bu konu ile ilgili ne düşünüyorsunuz? Bu görüşe sahip bir Türk ile karşılaşsanız 
ona ne cevap verirdiniz?" sorusuna verilen cevaplar da bunun farkında olduklarını göstermektedir. Birkaç örnekle bu açıklamayı somutlaştırmak gerekirse;

Abdurrahman: Bu topraklarm hepsi Allaha aittir. Biri bana böyle bir şey söyledi ben dedim biz talep etmedik devlet bunu bize veriyor. Gidin devlete söyleyin bize söylemeyin. Önce de ilk geldiğimizde böyle oldu. Arayıp emniyete gideceksin dediler gittik. Devlet bize yol gösteriyor biz onu yapıyoruz. O kişilerin elinde olan bir şey değil.

Shadi: Bazı Türkler bizim Türk vatandaşı olmamızı istemiyorlar. Onların da kendilerine göre hakl sebepleri vardır mutlaka.

Görüşmeler sırasında karşılaşılan ilginç noktalardan birisi de vatandaşlık verilmesini istemeyen Türklerin haklı olduklarına ilişkin görüşlerdir.

Yusuf: Türklere hak veriyorum, burası Türklerin kendi vatanı bizim vatanımız Suriye, savaş bitinceye kadar Türkiye bizi misafir etsin ama hakkımızı da versin savaş bittiği zaman biz geri dönelim.

Firas: Haklısın derim. Şimdi en azından biraz çekiniyorlar vatandaş değiller bir de onlar vatandaş olduktan sonra bir başınıza çıkmadıkları kalır. Bu Şükran mahallesine ben şu halimle giremiyorum. Bir gün önce Antalya'da göç idaresindeydim. Bir Suriyeliyi tutmuşlar. Sordum ona sen ne yaptın, niye buradasin diye. Bir şey yapmadım tabancayı gördüler dedi. Ben de ona dedim ki şehrin içerisinde tankla gezseydin. Ona göre tabancayla gezmek gayet doğal bir durum. Böyle insanlara bir anda vatandaşlık verildiğini düşünün bence olmaz.

Abdüllatif: Haklılar abla çünkü düşün bak bir eve misafir gidiyorsun, en güzel yemek istiyorsun, misafir hiçbir şey ister mi, verilirse alır. Ama biz istiyoruz, ev sahipleri de bize kızyor. Bence verilmemeli, bize kızmasınlar.

Görüşmelerde dikkat çeken önemli noktalardan birisi de Suriyelilerin de büyük kısmının herkese vatandaşlık verilmesinin yanlış olacağını düşünmesidir. Görüşmelerde buna ilişkin pek çok söyleme rastlansa da temel birkaç tanesine değinmek yerinde olacaktır. Bu noktada Suriyelilere "Sizce kimlere vatandaşlık verilmeli? (bu kişilerde hangi kriterler aranmalı?) Sadece sermayesi olan (yatırım yapan) ya da nitelikli/eğitimli Suriyelilere vatandaşlık verilmesine ilişkin talepler var. Siz bu konu da ne düşüyorsunuz?" şeklinde bir soru yöneltilerek bu konudaki düşünceleri ortaya koyulmuştur. 
Mirvan: Biz bu ülkeye borçluyuz, bu ülke olmasaydı bize kimse yardım etmezdi, Suriye'de ölürdük, bu ülkeye faydalı olan faydalı olacak kişilere vatandaşlik verilsin ama zarar olacak kişilere vatandaşlık verilmesin. Gerekirse geçici vatandaşlık verilsin eğer çalışmıyorsa zarar peşindeyse vatandaşlığı elinden alınsın.

Haşim: Bana kalırsa o kimsesiz kişiler dışında herkese vatandaşlık verilmelidir. Onlarında artık buraya karşı bilinçli olması lazım. Gelip geçerken uğradığım bir yer olarak gördükleri yere kim, niye katkı da bulunsun ki. Şükran mahallesinde ki problemli insanlar dışında herkes vatandaşlığa sahip olmalıdır.

Ruksan: Önce sermaye sahipleri, okuyanlar, doktor, öğretmen bunlara verilmeli. İki kültür bu şekilde birbirine katılırsa çok daha iyi olur. Amerika'ya bakarsak aynısın görürüz. Hep başka ülkelerden bilim adamların alır fazla maaş verir onlardan faydalanır. Türkiye de bunu yapabilir. Ama sorunlu insanlar da var sizde olduğu gibi bizde de. Onlarm belli bir elemeden geçmesi doğru olurdu.

Bakıldığ 1 zaman Suriyelilerin genellikle kendilerinin de olumsuz tepkilerle karşılaşmasına sebep olan sorunlu kişilere vatandaşlık verilmemesi gerektiğini savundukları görülmektedir. Aynı zamanda Türkiye'ye bir minnet borçları olduğu ve bu nedenle faydalanabilecekleri okumuş insanlar ve sermaye sahibi olanların ilk etapta vatandaşlık almasının daha iyi olabileceğini düşünmektedirler. Bu konuda Ruksan'ın verdiği ABD örneği de dikkat çekmektedir. Nitelikli ve sermaye sahibi kişilerin Avrupa'ya gittiği bunun önlenmesi için de vatandaşlık verilerek çeşitli haklar elde etmelerinin ve şartlarını iyileştirmenin sağlanmasının yerinde olacağı düşünülmektedir.

Yusuf: Vatandaşlık kesin olarak verilecekse isteyen herkese vatandaşlık verilsin zengin eğitimli ayrımı yapılmasın Suriye'de yıllarca ayrım yapıldı burada yapılmasın. Şuan bile Suriyeliler arasında yardımlaşma yok, eğitimli zengin insanlar vatandaşlık alırsa diğerleri ne yapacak? Diğerleri Türkiye'ye zarar verir bu kişiler çalışmaz, dilencilik ve suçlar daha çok artar şuan bile haberlerde görüyoruz.

Farklı bir perspektifle Yusuf herkese vatandaşlık verilmesini, ayrım yapılmamasının gerektiğini belirtmiştir. Bir ayrım söz konusu olursa onların buraya kin duyacağı, sorunlar çıkartıp çalışmayacağını düşünmüş ve ayrımın yanlış olduğunu belirtmiştir. Muhammed'in haklı olduğu noktalar olmakla birlikte bir elemeden geçirmeksizin herkesin vatandaşlığa alınmasının daha sonraki süreçlerde büyük sorunlar ortaya çıarabileceği ihtimali göz önünde bulundurulmalıdır. 


\section{SONUÇ}

Orta Doğuda yaşanan Arap Baharı'nın 2011 yılında Suriye'ye sıçramasıyla birlikte Suriye diğer ülkelere nazaran çok daha sert ve kanlı bir süreç geçirmiş ve iç savaş bugünkü boyutlarına ulaşmıştır. Dolayısıyla Suriyeliler çözümü başka ülkelere sığınmakta bulmuş nitelikli, eğitimli ve zengin olanlar Avrupa'da kabul edilirken diğer kesimler ise Mısır, Lübnan, Türkiye gibi ülkelere sığınmışlardır. En çok sığınmacıya ev sahipliği yapan Türkiye'de ise günümüzde ortalama 3.5 milyon Suriyeli bulunmaktadır. Türk halkı devletin Suriyelileri kabulüne karşı tepki göstermemiş aksine onlara kucak açarak her türlü yardımda bulunmuştur. Ancak geçici olarak geldikleri varsayılan ve bu anlamda kabul gören Suriyelilerin giderek kalıcı hale gelişi, Suriyeli bazı bireylerin çıkardığı sorunların herkese mal edilerek yansıtılması ve tahammül sınırlarının aşılmaya başlamasıyla birlikte Suriyeliler sorunu ortaya çıkmaya başlamıştır. Bu anlamda en önemli sorun ise geçicilik üzerine kurulan politikaların yetersizliği üzerine vatandaşlık söyleminin gündeme gelmesiyle başlamıştır.

Vatandaşlık Suriyeliler için elzem bir konu olarak karşımıza çıkmaktadır. Şu anda Cenevre Sözleşmesine getirilen "Avrupa'dan gelen" şartı ile mülteci statüsüne giremeyen Suriyeliler sığınmacı statüsünde yer almışlardır. 2013'te eksikliklerin görülmesiyle birlikte yeni bir kanunla şartlı mülteci, geçici koruma, ikincil koruma gibi terimler eklenerek Suriyelilerin geçici koruma statüsüne alınması ve bu bağlamda kimliklerinin oluşturulması gerçekleşmiştir. Ancak artık dönme ihtimallerinin azaldığı düşünüldügüünde ve buna yönelik çalışmalarda da dönmek isteyenlerin gün geçtikçe azaldığı görüldügünde vatandaşlık istemi gündemdeki yerini almaktadır. Evlenme, evlat edinme gibi şartlarla anayasada vatandaşlı̆̆ın mümkün olabileceği belirtilse de 5 yıllık ikamet ile vatandaş olma hakkı geçici koruma statüsüyle birlikte engellenen bir durum olmuştur. Suriyeliler de bu anlamda geleceklerine dair endişeler taşımaya başlamış ve vatandaşlık talebinde bulunmuşlardır.

Suriyelilerin aksine Türk halkı ise Suriyelilere vatandaşlık verilmesine çok büyük oranda karşı çıkmakta, kalıcı olmalarını istemeyerek savaş bittiği takdirde dönmelerinin sağlanması gerektiğini düşünmektedir. Bu duruma milli ve kültürel unsurlar, Suriyelilerin şu an bile sorun çıkarırken 
vatandaşlık alırsa daha rahat olup daha çok sorun çıkaracağı endişesi, kalıcı olmalarını istememe, ekonomik etkenler gibi pek çok sebep sunulmaktadir.

Suriyeliler de bu tepkileri görmekte ve istenmediklerine şahit olmaktadır. Bir kısmı bu konuda Türklere hak verirken bunun sebebinin sorun çıkaran Suriyeliler olduğu ve onların gönderilmesinin en doğru çözüm olacağını belirtirken bazılarının da şikayet edilen konuların vatandaşlıkla gelecek yükümlülüklerle birlikte önlenebileceği düşüncesine sahip olduğu görülmektedir.

Suriyelilerin bir kısmının ifade ettiği gibi günümüzde sorun olarak görülen Suriyelilere ilişkin pek çok husus vatandaşlık verilmesiyle çözülebilecek boyuttadır. Vatandaşlık verilmesiyle birlikte onların da vergi gibi yükümlülüklerinin olması ayrıca sermaye sahiplerinin burada kalmasının sağlanarak yatırım ve ticaret yapmalarının önünün açılması gibi pek çok husus sorunları önlemekte önemli bir yer edinmektedir. Aynı zamanda Suriye'de savaşın daha uzun yıllar süreceği görülebilmekteyken orada hiçbir şeyi kalmamış milyonlarca insanın oraya dönüp sıfırdan bir şeyler yapma ihtimali giderek düşmektedir. Gidip orayı yeniden inşa edecek olanlar yine eğitimli kesim olacakken kalan büyük çoğunluk burada kalıc1 olacak, ülkesine dönmeyecektir. Bu anlamda onların da geleceklerini garanti altına almak ve bir kimlik oluşturma sürecini başlatmak elzem bir meseledir.

\section{KAYNAKÇA}

Aile ve Sosyal Politikalar Bakanlığı (2016). Türkiye'de Geçici Koruma Statüsündeki Suriye Vatandaşlarına Yönelik Sosyal Uyum ve Psikososyal Destek Çalışmaları Koordinasyon ve Planlama Çalıştayı. http://ailetoplum.aile.gov.tr/data/5429366a369dc32358ee2a92/calistay raporu.pdf, erişim tarihi: 25.05.2017.

Anbarlı Bozatay, Ş. (2010). 5901 Sayılı Türk Vatandaşlı̆̆ı Kanununa Göre Türk Vatandaşlığının Kazanılması. Yönetim Bilimleri Dergisi, 8 (2), s. $165-182$. 
Çarkoğlu, A. \& Kalaycıoğlu, E. (2014). Türkiye'de ve Dünyada Vatandaşlik.http://bilimakademisi.org/wp-content/uploads/2015/12/T\%C3\%BCrkiyede-ve-Dunyada-Vatandaslik-20141.pdf, erişim tarihi: 25.05.2017.

Erdoğan, M. (2014). Türkiye'deki Suriyeliler Toplumsal Kabul ve Uyum. HUGO ( Hacettepe Üniversitesi Göç ve Siyaset Araştırmaları Merkezi). https://data2.unhcr.org/en/documents/download/46184, erişim tarihi: 05.03.2017.

IMPR (Uluslararası Ortadoğu Barış Araştırmaları Merkezi) (2014). Türkiye'de Bulunan Suriyeli Mülteciler. http://imprhumanitarian.org/tr/infografik-rapor-turkiyede-bulunan-suriyeli-multeciler/, erişim tarihi: 05.03.2017.

KONDA \& İPM (İstanbul Politikalar Merkezi) (2016). Vatandaşlık Araştırmas1. http://www.birarada.org/upload/Node/26816/files/VatandaslikArastirmasiRapor.pdf, erişim tarihi: 25.05.2017.

Koyuncu, Ahmet (2016), “Nimet mi? Külfet mi? Türkiye'nin Suriyeli S1ğınmacıları ve Göç Ekonomisi Üzerine Bir Derkenar", Türkiye'de Geçici Koruma Altındaki Suriyeliler: Tespitler ve Öneriler. Dünya Yerel Yönetim ve Demokrasi Akademisi Vakfı (WALD). Ed. Adem Esen, Mehmet Duman,İstanbul: WALD yay.,ss. 107-130.

MÜSİAD \& MEVKA (2015). Konya'daki suriyeli misafirlerin ekonomik potansiyelleri ve işbirliği imkanlarının belirlenmesi araştırması.

ORSAM (Ortadoğu Stratejik Araştırmalar Merkezi) (2016). Türkiye'deki suriyeli mülteciler: uzun vadeli entegrasyon için firsatlar ve zorluklar. http://www.orsam.org.tr/files/T Degerlendirme/1/1tr.pdf, erişim tarihi: 25.05.2017.

SETAV (Siyaset, Ekonomi ve Toplum Araştırmaları Vakfı) (2015). Türkiye'deki suriyelilerin hukuki durumu: arada kalanların hakları ve yükümlülükleri. $\quad \underline{\mathrm{http}: / / \text { file.setav.org/Fi- }}$ les/Pdf/20151230134459 turkiyedeki-suriyelilerin-hukuki-durumu-pdf.pdf, erişim tarihi: 25.05.2017.

TBMM Araştırma Merkezi (2011). Ülke Anayasalarında Vatandaşlık Tanımları. https://anayasa.tbmm.gov.tr/docs/vatandaslik_tanimlari.pdf, erişim tarihi: 25.05.2017.

Uğurlu, C.T. (2011). Avrupa birliği ülkelerinde ve türkiye'de vatandaşlık eğitimi. Elektronik Sosyal Bilimler Dergisi, 10 (37), 153-169. 
URL1: http://www.bbc.com/turkce/36802877, erişim tarihi: 27.05.2017.

URL2: http://www.diken.com.tr/doc-dr-erdogan-kimse-istemiyor-amasuriyelilere-vatandaslik-verilmesini-konusmamiz-gerekecek/. Erişim tarihi: 27.05.2017.

\section{KaynakçaBilgisi / Citation Information}

Gülyaşar, M.(2017). Suriyeliler ve vatandaşlık: Yerel halk ve suriyeli sığınmacılar çerçevesinde bir değerlendirme. OPUS - UluslararasıToplumAraştırmalariDergisi, 7(13), 678-705. 